\title{
Benjamin Cohen on global political order: when Keynes meets realism - and beyond*
}

\section{Stefano Guzzini**}

\section{Introduction}

How best to understand world order? This perhaps most typical of 'political' questions led many IR scholars to turn to IPE. It was less surprising than it might have appeared at first. Since its origins in the 1970s and 1980s, IPE was not only a turn to economics as a field of 'low politics' that happened to significantly affect international affairs; just another subfield of IR, as it were. More ambitiously, it aspired to integrate economics into a more comprehensive vision of politics. It aimed at the very core of international 'high politics', constituting IPE as a field to supersede or synthesise IR (Strange 1994: 218).

\footnotetext{
* Received on January $1^{\text {st }} 2015$ and approved for publication on March $26^{\text {th }} 2015$. This is a revised version of a paper entitled 'Benjamin Cohen on global political order: variations on a Gershwin tune', presented at the joint FLACSO/ISA convention in Buenos Aires on 23-25 July 2014. I am most grateful for comments and suggestions by Jeffrey Chwieroth, Peter Katzenstein, and the referees of Contexto International. The usual disclaimers apply.

** Senior Researcher at the Danish Institute for International Studies, Copenhagen, Denmark; Professor of International Relations at PUC-Rio, Rio de Janeiro, Rio de Janeiro, Brazil; and Professor of Government at Uppsala University, Uppsala, Uppsala County, Sweden. Email: sgu@ diis.dk.
}

CONTEXTO INTERNACIONAL Rio de Janeiro, vol. 37, n³, september/december 2015, p. 851-887. 
This demand for IPE was prompted by the curiously narrow understanding of 'government' and politics that took hold of political science and even IR (see Gilpin's preface in Gilpin 1987). The former has been focusing on the policy process in domestic politics, increasingly neglecting the overall frame in which order is provided - a development that runs parallel to the marginalisation of classical political theory in most departments. On the side of IR, many political realists did place political order at the top of their research agenda. But they did so while blissfully neglecting economics, as if order, including its economic component, could be steered by a political sphere in which diplomacy ran the world still unfettered. ${ }^{1}$ Instead, as Cohen wrote approvingly about Susan Strange's approach, '[i]ssues of finance or currencies could not be relegated to the "low politics" of technical economics alone. Money is inherently political, an integral part of the "high politics" of diplomacy too" (2000: 91). In other words, IPE was not there to introduce economics into IR, but to rethink international politics by returning to the classical questions of the origins and dynamics of order and rule, or 'government' in the old sense. No wonder that it initially thrived at the meeting point between post-Marxist and neo-mercantilist scholarship. $^{2}$

I propose to read the work of Benjamin Cohen through this tradition and lens. In his earlier writings, Cohen comes out strongly in favour of a classical realist position, which translates realist Concert diplomacy into the (utilitarian rationalist) analysis of political oligopolies. It insists on a clear primacy of political factors, somewhat along the lines of Waltz's 'Structural causes and economic effects' (a telling chapter title in Waltz 1979). But over the years, he is not satisfied with that 'easy' structural answer, exposing the need, and sometimes pleading, for co-operation under anarchy in the governing of markets. Later again, he is bound to reflect on the resistance to such market-disciplining attempts, as in his discussion 
on capital controls. If anarchy does not exclude governance, as his early realist stance emphasised, and yet if governance is hampered by systematic tendencies that influence state and market power, as he critically reflected on the resistance to Keynesian policy tools, then a call for co-operation ends up sounding both politically right while theoretically begging the question. ${ }^{3}$ Hence he eventually turns to an analysis of the more structural and institutional aspects of rule that systematically bias the payoff matrixes of the global actors, be they firms, banks or states.

Cohen's perspective is, however, caught in a constant and central tension. On the one hand, he insists on the political necessity as well as (or so I would argue) the moral responsibility to act. It ain't necessarily so. On the other hand, his invitation to political agency takes place in a context not of individual autonomy and/or structural indeterminacy and contingency, but of mighty political and economic forces to be reckoned with. And so Cohen increasingly displays the same tension that can be found in other IPE scholars. Just as with Strange, the international Keynesian struggles with the political realist in a common concern about domination and dependence: 'Strange the Keynesian political economist believed that international economic regulation was absolutely necessary, yet was prevented by Strange the realist international relations scholar from seriously believing that such regulation was a possibility worth thinking about'(Leander 2001: 126).

The following will present the playing out of this tension in two steps. A first part will introduce Cohen's critique of economic determinism and early turn to political realism and then co-operation under anarchy. The second part will start from the Keynesian hangover when the reform of financial markets is marginalised by politicians and academics alike (in the core of power). It will then show the shift in Cohen's analysis of the political order of the world 
economy in which he takes up his earlier concern with the system of rule so as to understand the systematic (also 'economic') biases that apply to political ordering - in other words, mechanisms of order, actors and their preferences.

In the end, whether or not Cohen could avoid the realist-Keynesian tension, it was quite clear for him that the demand for IPE was driven by the need to engage the very paradigms that inform the observer. His approach to global political order is less an attempt to use order to explain ongoing policies as an empirically driven conceptualisation of that very order in the first place. I will therefore end by arguing that his recent methodological writings that expose a rift between British and US approaches to IPE are logically connected to his approach to order. For Cohen, we miss better constitutive theories, that is, frameworks that allow us to better capture empirics in the first place. Hence, a reduction of theorising to empirical generalisations, as prevalent in the US, is part of the problem, not the solution. They are 'boring' as he says, because they literally miss the point of IPE and the relevant way to do it. Cohen's focus on global political order logically implies and pleads for a certain vision of (theorising) IPE.

\section{Governance I: between power politics and co-operation under anarchy}

It surely is not self-evident that an educated economist who had worked at the Federal Reserve would write a book taking a heads-on approach to post-Marxist theories of imperialism. Self-respecting specialists on banking do other things. And yet, for my reconstruction, this book is crucial for understanding Cohen's international theorising and its focus on the central role of rule and hierarchy in the world political economy. It is not that Cohen would look at post-Marxist theories just as a foil for a scholarly 'wrecking 
exercise'; rather, he sees them often asking the right questions, but giving mostly erroneous answers, or at least too trenchant ones.

Post-Marxists are intriguing for Cohen, since they share a starting point: international relations are fundamentally about domination, and their study must elucidate the origins and implications of that domination. While we have increasingly come to think about theorising international relations mainly in terms of theories of action (whether behavioural, wider rationalist, or norm-constructivist), realists and Marxists tend to use theories of domination as paradigmatic for understanding politics. Not surprisingly, therefore, his definition is relatively wide: '[Imperialism] simply refers to any relationship of effective domination or control, political or economic, direct or indirect, of one nation over another' (1973: 16, emphasis in the original). The study of political economy is fundamentally about power, and the understanding of power fundamentally needs a study of the political economy.

As this section will show, Keynesian optimism and a sense of political responsibility make Cohen oppose Marxist theories of imperialism. He does not deny that economic logics are at work in the world order, but sees them as ultimately checked by political logics. He does not deny international domination and dependency in that world order, but sees them as a result of the specific effects of international anarchy. In the context of the post-Bretton Woods regime, this produces a vision of the world order as the result of a political oligopoly. With this focus on agency, Cohen then basically opts for a rationalist approach to understand the possibilities and limits of co-operation for providing that order. This first phase combines an economist's response by keeping economics and politics separate, and a realist's response which gives primacy to political competition: economics are what they are, but it is really politics which messes or cleans things up ([1976] 2008: 27). 


\section{No economic necessity: governance as power politics}

In his discussion of theories of imperialism, Cohen combines classical debates that centre on the needs of the core capitalist countries, or the system of capitalism as such, and those that centre on the receiving side. Despite an apparently clear verdict that all these theories try to prove too much and misunderstand the basic political dynamic of world order, his discussion will show a remarkable agreement on many points.

In his critique of theories that derive imperialism from the inherent needs of the leading capitalist economies, Cohen basically uses Keynesian responses to what he sees as existing problems of capitalism or market economies. Under-consumption is not necessary, although it will cyclically appear. Given a series of anti-cyclical macroeconomic tools like price reductions, distributional policies and public investments, however, this can be remedied (1973: 57). Similarly, the rising organic composition of capital (a declining rate of profit) can be offset by technological change, population growth or income redistribution, and direct civilian expenditure by the government, and 'then demand for capital should rise at least as rapidly as supply’ (1973: 59, 115-18).

Hence his repeated Gershwin tune of 'it ain't necessarily so'. 'It is possible that aggregate profits will tend to rise relative to national product through time ... it is even possible that profit rates will tend to rise. But it is equally possible that these trends will not appear. In oligopolistic markets we just cannot know a priori' (1973: 112, emphasis in the original). Imperialist theories try to prove too much: '... that trade and investment connections are necessary (in the sense that without them centre countries would unavoidably sink into stagnation and unemployment), that economic imperialism is inevitable (in the sense that the capitalist system as a matter of course must generate behaviour classified in this way)' (1973: 133-34, 
emphasis in the original). In short, critiques of capitalism go wrong when they underestimate 'the reformative capacity of modern capitalism' (1973: 118).

With regard to those theories that address imperialism from the periphery, Cohen shares the assessment that capitalism is not necessarily moving countries out of the periphery. How, then, can 'economic relations with the metropolitan center ... generate and perpetuate poverty in the periphery?' (1973: 155). Cohen has no qualms seeing how capitalism can be directly connected to poverty. In trade, for instance, he sees that there can be a tendency to encourage a division of international labour where the local production in LDCs has few forward-backward linkages (for an analysis of those linkages, see Sen 1984), as well as consumption patterns that will encourage more imports and less savings (Cohen 1973: 178ff). He sees the risk of a continuous foreign exchange gap, and argues that dependency scholars are correct in seeing LDC economies skewed in their allocation of resources and dominated by developments outside their control. Indeed, 'I said that the reason for this skewness [of resource allocation] lies in the biased global structure of capitalist prices. To this extent capitalism can be held responsible as the cause of the present dependent condition of the poor' (1973: 202).

Out of this, he makes two claims. One is to see a tendency but no necessity, and so we come to the prevalent Gershwin doctrine:

Economic relations with the rich may not always be an engine of growth for the poor, but they can certainly have that effect at times. Trade and development need not necessarily result in greater poverty in the periphery, but they can certainly have that effect often enough. It all depends on the circumstances..... I mean to suggest that exploitation is not inherent in the present organization of 
international economic relations' (1973: 168, 218 , emphases in the original).

The other claim is that these effects are not driven by the needs of multinational corporations, as many imperialist theorists would have it, and that governments are not doing this because of the needs of international capitalism but for reasons of power and prestige: 'The logic of domination derives directly from the existence of competing national sovereignties. Imperialism derives directly from this crucial defect in the external organisation of states' (1973: 245, emphasis in the original). The drive for power and prestige is hence the logical consequence derived from international anarchy. The resulting international system is akin to economic oligopolies and can be analysed accordingly (1973: 239ff). With this fundamentally (neo)realist explanation, economics is part of the story, yet not the ultimate driving force:

To this extent, there is little point in distinguishing at all between economics and politics in a discussion of international relations, since both are essential elements in the perpetual struggle for survival. However, this does not mean that economic factors are therefore the ultimate driving force in the struggle for survival (1973: 249, emphasis in the original).

\section{No political fatalism: governance as co-operation under anarchy}

Cohen follows up on the political possibility of reforming capitalism and of cushioning the negative effects it can have. The argument proceeds in two steps. First, even if competition/self-help stems from anarchy and the fundamental struggle for survival, this does not imply that the system is without rule or order. And secondly, if that 
order is to be understood similar to economic oligopolies, this opens up for the possibility of collaboration in some sort of economic 'concerts'. Politics is here not only in the theoretical driver's seat for the underlying explanatory logic, but also for the practical governance of the world. Economic relations will be merely the field in which this political steering will take place.

The starting point for the analysis is again basically realist: it is easier to impose economic order if there is only one 'orderer' around. The basic realist inspiration of Hegemonic Stability Theory is not difficult to understand. Some order is to profit everyone (or at least a majority of players), but to get there, the most efficient way is to have a single authority imposing it. Short of a world government to play the international Leviathan, a single hegemonic state will do.

This said, Cohen sees no way the United States would still be able to impose that order. The main reason is not so much (at least not until the 1990s) that other states are challenging US power to an extent that would effectively undermine its leadership. Rather, with the privatisation of the creation of international liquidity,

... the key of the dilemma lies in the US government's limited influence over the banks, which can best be understood in terms of the continuing dialectic between the 'market' and the 'state'.... In effect, the market moved beyond the influence of any one state, even that of the former hegemonic power (Cohen 1985: 726).

To contain such market forces, political actors have to act together. And here, any solution which decentralises control, leaving it to regulations adopted by individual countries, will be insufficient. The solution is not only a common one, but involves a collective aspect in which policies are conceived and applied together, so that actors pool at least some resources and instruments (Cohen 1996: 273). 
From the social contractarian set-up (the rational choice in favour of a collective Leviathan) and strategic interaction for mutual benefit, Cohen easily moves into a rationalist and basically economist approach in terms of cost-benefit analysis and game theory. Politics is possible, co-operation can happen, but for this to take place it needs to pay off. Luckily, the theoretical case for co-operation is not problematic, since one can show that governments can collectively find and apply policy instruments which they lack individually. And so, even selfish players can find themselves demanding co-operation in search of Pareto optimality, as neo-liberal institutionalism would have it (Cohen 2000: 106-07).

But then, in a classical utility analysis, the costs may outweigh the benefits, and so Cohen finds at least five reasons why such co-operation may not materialise, all related to the initial calculus: the magnitude of the gains, the magnitude of the costs, time-inconsistency problems, distortion of incentives, and model uncertainty (Cohen [1993] 2008: 58-60). As he writes:

[i]n the language of game theory, much depends on the details of how the strategic interactions are structured, for example, the number of players in the game, whether and how often the game is reiterated, and how many other related games are played simultaneously' ([1993] 2008: 59).

By 2008, with the experience of many crises, and still limited co-operation to rein in their origins, and given 'the ever-widening circle of actors and interests involved today, ... [t]he "non-system" has never seemed more rudderless. ... Short of a major crisis, prospects for effective governance remain regrettably dim' (2008: 17).

In other words, the prospects for effective governance seem to be stuck in a Nash equilibrium, which is sub-optimal. Except for major 
external shocks which would profoundly alter the pay-off structure and hence the calculus of the actors involved, it will probably not happen. No necessary fatalism, but not much optimism either. This indictment does move responsibility to political and other actors for not stemming the tide and for not accepting some short-term costs in view of potential long-term benefits. It also accepts, with some sigh of resignation, that an interest-driven politics will remain stuck.

The implications for understanding governance are manifold. For one, there is a tendency to reduce the analysis of governance to the 'steering capacity' of actors without further analysing the system of rules within which this takes place, and which may not only define the means and pay-off matrixes but also the very preferences of those actors in the first place. This move also implies that any attempt to render the analysis of power more structural is re-translated into an interactionist social exchange model. The conceptualisation of power is done in economic terms, such as in Keohane's and Nye's Power and Interdependence (1977). Its economic inspiration probably derives from Al Hirschman's early analysis of economic power ([1945] 1980). This works on an analogy between the analysis of power and of trade dependence, or simply price elasticity. In those cases where traded goods are easily substitutable (trade elasticity of substitution), no major dependence derives should the exchange stop; dependence results, however, if the goods are not easily substitutable. As an analogy, power is more significant if derived from 'vulnerability' interdependence with lacking substitutability than from mere 'sensitivity' interdependence (Cohen 1973: 241). ${ }^{4}$

From here, it is a logical step to reading Strange's approach to structural power as the mere aggregation of vulnerability interdependence:

Power at the structural level may be understood to be a direct function of the cumulative total of asymmetrical 
relationships. The greater the number of asymmetries that favour one country, relative to those that disfavour it, the more structural power it will have; and the more structural power it enjoys, the more intensive it has to seek to extract by favourably modifying the existing framework (in game-theory terms, to favourably restructure the payoff matrix). The task of theory would then be twofold: to identify the key conditions that determine, first, when power at either level is or is not likely to be used (that is, when the incentive will or will not be acted upon); and second, when the use of power is or is not likely to be successful' (Cohen 2000: 99, emphasis in the original).

Not only does this interpretation do insufficient justice to Strange's conceptualisation (for a discussion, see Guzzini 1993; 1998: 176-82; 2000); it also reduces the analysis of power to direct coercive power or to indirect institutional power (when influencing the payoff matrix). ${ }^{5}$ Moreover, to arrive at the structural level in this bottom-up way assumes that we have a measure with which we could combine or accumulate all these asymmetrical relationships into a single power indicator whose absence was one of the factors that pushed Keohane and Nye into asking for an analysis of separate issue areas in complex interdependence in the first place. ${ }^{6}$ In fact, the 'greater number' of asymmetries may not mean much without such common indicator with which to aggregate them. It is again the issue of the lacking fungibility of power resources that makes this impossible. ${ }^{7}$

Hence, Cohen's utility-maximising economic framework cannot account for the impersonal effects of structures in systematically mobilising biases of domination and dependence. ${ }^{8}$ This becomes very visible when Cohen uses Lukes's three faces or dimensions of power (Lukes 1974). Lukes famously distinguished between a first dimension of power which is about direct coercion, a second which is 
about indirect agenda-setting, and a third one where power is at its most insidious since it pre-empts a conflict from even arising because the actors involved either come to believe that they share the same interests, or have a naturalised understanding of their political environment such that they would literally not be able to see their diverging interests. This third dimension is about structural factors and their effects on the formation not of preferences due to a changing payoff structure, but on the formation of interests themselves. It is not that actors still want the same thing, but adapt their preferences to the new situation available; they have come to be or are locked into not wanting these things in the first place. They have come to be or are locked into interests that pre-empt their resistance against the structure of domination and the people who profit from it, whether the latter actively advance those interests or not.

There is a long discussion on how we may know what people 'really want', i.e. about some version of 'false consciousness', and the risk of importing the value judgements of the observer into the analysis. However, this critique is far less decisive than it may seem at a first glance. Although being value judgements, they need neither be subjective nor unrelated to empirics. In fact, they inform 'acceptable' behavioural theories. The idea of an observer having an access to the 'real' interests of people can be based on the idea of human needs, such as security, wealth, social recognition, and so on. ${ }^{9}$ A social arrangement that systematically and negatively affects these needs can be seen as against the person's interest. The assumption of 'survival' does the same job in realism.

In fact, 'false consciousness' includes an empirical claim as a power mechanism and its effect on human needs provision, and a normative one as whether this is morally acceptable or not. On the empirical level, the power mechanism that works on the minds of people is not easily observable, yet the analysis of propaganda, which relies on the same mechanism, is a staple good of political analysis as well as 
marketing studies. The analysis proceeds via universals. Its effect on human needs could not count as an empirical claim only when any idea of human universals is excluded from empirical analysis. But usually, IR scholars and liberal critiques of 'false consciousness' are informed by rational choice and utilitarian theories of action which are based on the assumption of the universal feature of human rationality. And second, on the normative level, if indeed the liberal idea of personal autonomy being in the universal interest of a (liberal) citizen is the starting point, as it is for most scholars criticising the idea of 'false consciousness', then all arrangements that unduly restrict such autonomy (via the social system of rule) can be seen as opposing the citizen's interests.

The unease with such an explanation stems from elsewhere. Such power analysis does not only involve an indirect influence through the mind and interest formation, but also does not necessarily rely on the intentionality of the power holder, whoever this may be. It is explicitly not limited to a kind of collective and master-minded brain-washing that goes on to lure people into false beliefs. Although this can well exist, it is not constitutive for it being an issue of rule and power. As Peter Morriss (1987) has argued, the issue of assessing power is not whether some people wanted to dominate, but whether they are part of a system where they do.

By being an indirect effect and of diffused or systemic origins, however, the empirical power analysis seems to slip through the hands of the observer. The inclination is therefore great to reintroduce ideas of agency and intentionality, only to find such masterminds then hard to pinpoint. And so, when Cohen borrows this Lukes-inspired discussion from an article by Scott and Lake, he also explicitly follows them in reducing the third face of power to mere 'propaganda, in the broadest sense of the word, to influence the climate of opinion in foreign countries' (James and Lake 1989: 4) ${ }^{10}$ as if the effect of 'ideas and ideology, shaping the climate of opinion' (Cohen 1996: 277) was reducible to intentional agency. 
It is as if the 'Gershwin doctrine' played a trick on Cohen's argument at least until the end of the 1990s. Insisting that politics is possible, that actors can co-operate, and that generalisations in terms of structural necessities are actually unnecessary, his initial concern with the way the world is ordered and domination to be understood has given way to a concentration with strategic games in which IPE merely adds economic actors such as banks to the fray. It is as if making an argument about the global political economy displaying structural features would exclude political agency or responsibility, and hence needs to be dismissed. When he writes that '[g]lobalised financial markets, it seemed, had become something akin to a structural feature of world politics: an exogenous attribute systematically constraining state action, rewarding some behaviour and punishing others' (Cohen 2008: 10), he actually seems to share the idea that there are such features, but does not subscribe to the implication that no agency or change is possible.

Yet, this implication, in turn, 'ain't necessarily so', because making structural features endogenous, as Cohen attempts to do, does not require a relapse into a purely individualist and economic utilitarian account. Even for structuralists, they are not exogenous in a fundamental sense, since all structures are reproduced through social practices. This does not rule out change; it only makes it potentially difficult, as his analysis on the debate and policies of capital control will show. Furthermore, it allows for the possibility that actors believe being confronted by an exogenous and unchangeable social world; a belief that, in turn, affects the social world.

The next section will suggest how Cohen moves to a more structural account. He remains torn between a fundamental interest in who and what governs the world which has led him to emphasise structural forces, and an approach that yet allegedly needs to eschew 'exogenous' structural features. It is further argued that although this tension remains eventually unresolved, Cohen increasingly acknowledges it. Were his earlier studies reducing the origins of 
order to political agency (or the lack thereof), his later studies return to the interest in the role of capitalism (his code word: "market-driven competition').

\section{Governance Il: between steering capacity and a system of rule}

WHAT HE SAID: It is this Government, this New Labour Government that has cut capital gains tax further than ever before. We have been listening to business. - Tony Blair, Prime Minister, speech at the annual dinner of the Confederation of British Industry (CBI), 17 May 2000

WHAT HE MEANT: We have been buggered by business.

WHAT HE SAID: New Labour does not believe it is the job of government to interfere in the running of business. - Tony Blair, Speech to the Nottingham Chamber of Commerce, 19 January 1996

WHAT HE MEANT: We enjoy being buggered by business. ${ }^{11}$

Cohen has advocated selective versions of capital control to stem the 'ever more pervasive influence of capital mobility over outcomes in monetary affairs' (2008: 7). In a good Keynesian manner, effective economic and fiscal policy is made possible by not letting capital markets free. He is emboldened by the support of some market actors, like George Soros. More importantly, governments have used it, as did Malaysia in response to the 'Asian crisis' - and with good effect. But then: that was more or less the end of it. No government and surely no international coalition of governments went for it. And 
so he wonders: 'Why should governments be forced to make all kinds of sacrifices to appease market forces?' (2008: 13) Why indeed?

This section weaves a series of threads together in order to show how Cohen's answer and later writings return to a stronger focus on domination within governance and the world order. With this, he more explicitly integrates the analysis of the 'structures of power' and global capitalism into his own approach. This claim is elaborated in two steps: first by showing how this analysis increasingly includes ('endogenises') interest formation for understanding individual behaviour; and second, by showing his return to the issue of hierarchy and stratification in the global order in his analysis of currency competitions, where, eventually, politics can make only a difference to a game that is already set for it. This portrays an image of the world political economy in which all of us are in some kind of periphery. Governance is no longer understood only in terms of steering capacity, but as a system of rule.

\section{Endogenising interests: the origins and dynamics of pay-off matrixes (or Keynesian optimism betrayed)}

How come governments 'enjoy being buggered by business'? In his earlier writings, Cohen had rejected theories of imperialism for being unable to show the direct causal link between business influence and government politics. He noted that for some writers like Magdoff, this is not the issue, since 'what is really at stake is global capitalism itself' (1973: 127), and the effects capitalism has on all actors, whether business or governments. But, in the end, he is not convinced. For one, he cannot find a clear convergence of interests 
between business and governments. Moreover, even if there were, it 'could equally indicate that special interests were simply being used as convenient tools to accomplish the independent objectives of the state...' (1973: 71). Probably afraid of the alleged tendency of such structural arguments to be non-falsifiable, he insists on a narrow empirical proof, namely '... that corporations or industries are capable of controlling, or at least substantially influencing, the foreign economic policies of their national governments' (1973: 141).

Yet he seems less convinced about the set-up of his argument in later writings. A theory of imperialism dedicated to showing the effect of capitalist actors on politics may be apprehended in his way. But with the coming of neo-liberalism and the Washington consensus, the question is less, or at least not only, whether there are powerful groups that have set the political agenda. ${ }^{12}$ The question is not whether 'capital' pushes the state to expand for its interests, but rather whether 'capitalism' itself is expanding to include more and more sectors into the market nexus, commodifying anything from education and health to national security, undermining political autonomy, and reducing the scope for public governance as steering capacity. That the states themselves have let the genie out of the bottle is secondary for this argument, and of little comfort (for early statements of this point, see Strange 1986; Helleiner 1996).

This can be re-translated into a more choice-theoretical approach used by Cohen, as developed above. The question then becomes whether or not actors get stuck in a sub-optimal game whose iteration shapes the payoff matrix such as to further solidify the sub-optimal equilibrium. Actors' repeated interaction would hence expand the scope of the market nexus and thus systematically diminish the 'reformative capacity of modern capitalism'. This may or may not be the actual intention of any of the actors involved; but short-term 
utility may undermine their long-term preferences by influencing the very game in which the interaction takes place. No conspiracy or grand theory is needed: only the interaction of 'market-driven competition' and competing political actors.

Cohen repeatedly strays from this path. Prompted by the discussion on capital controls (and their neglect), he comes to insist that the analysis needs to put market forces on an equal analytical footing with public policies. And he favours a time dimension in the analysis, where, as he quotes approvingly from a piece by John Goodman and Louis Pauly, 'government actions in one period leading to increases of capital mobility that in turn have generated pressures for widening liberalisation in subsequent periods' (1996: 279). ${ }^{13}$ Hence, it becomes possible to think that, by influencing actors' preferences, lock-in effects will increasingly bar any other path.

One of the possible implications of this concern with interest formation is that the very economistic choice-theoretical setup is becoming insufficient. A classical utilitarian choice model would see preferences change only in terms of how otherwise fixed interests can be best reached in changing payoff matrices. In parallel to the then rising constructivist research in IPE, it seems, however, that Cohen is ready to open up that Pandora's box where the analysis of games would start with the way in which interests are formed in the first place. The concern is, as John Ruggie put it, "what happens before the neo-utilitarian model kicks in', where beliefs and shared ideas are "not simply "theoretical filters", to use Mark Blyth's apt term, employed to shore up instrumental accounts, but that in certain circumstances they lead states to redefine their interests or even their sense of self' (Ruggie 1998: 867, 868).

Hence, structural factors have made a comeback with Cohen's move to a dialectical take on politics and 'market forces', and their effect on agents' interest formation. In my understanding, this comeback also 
has to do with Cohen's continuous aim of analysing hierarchy and the stratification of the international order. If he could write that, for his argument, 'it does not matter where the policy preferences of governments come from. It only matters that they act systematically on them' ([1993] 2008: 74), then this may, at most, apply to a behaviourist input-output analysis of action. An analysis of domination would surely want to know where those preferences that can assure such systematic behaviour come from. In other words, allowing independent structural or 'social' features into the framework of analysis opens up for a type of theorising where a theory of domination is not necessarily reduced to a theory of action. The analysis of governance needs to understand a system of rule that is constituted by social practices and institutions which kick in before agents make their choices.

\section{The rules of the game rule: world hierarchy and market-driven currency competition}

In his analysis of the global political order, Cohen similarly strays from a purely agency-oriented analysis to accounts where the rules of the game rule. Consistent with a focus which looks at order from the side of the orderer, Cohen captures the competition that has broken out between currencies. But, different from the early writings, the whole is set against the background of market forces to which political and social actors can only more or less successfully adapt. Their competition no longer defines the terms of the game; the market does. Governments can affect the outcome in the game, but no longer the game itself. With capital mobility, politics can still go on, but the Keynesian dream is over. His argument makes this more structural argument often only implicitly, though, because the focus 
stays on actors, governments and market forces (or private social actors). ${ }^{14}$

Still, the argument considerably widens the view of governance, going beyond governance in terms of mere (public) steering capacity. His starting point, and that of many others, is the diffusion of authority in the global political economy. Not content to think about politics only in terms of governments, he looks for a deterritorialised vision of politics that combines functional and territorial components. ${ }^{15} \mathrm{He}$ now conceives of governance as a system of rule that can be indirect, and driven by impersonal market force - 'but that does not make them any less capable of governance' (1998: 145). The world has become a heterarchy - neither anarchy nor hierarchy (Onuf and Klink 1989) - as exemplified in financial matters by a currency pyramid.

With this vision of governance in mind, both horizontal and vertical, Cohen assesses the change that governments have undergone in the power they could potentially derive from their former monetary monopoly to the present situation, where they have to share it with market actors. In all four domains (political symbolism, seigniorage, macroeconomic management and monetary insulation), the governments have to adapt to the game: '... a much healthier economic performance may be attained, with lower costs of adjustment, if governments in effect submit their nominal sovereignty, at least in part, to the strict discipline of the marketplace' (Cohen 1998: 126).

This discipline does not only apply to the bottom currencies. With regard to market forces, we have all become peripheral, if in different ways.

And even for the favoured few near the top, policy autonomy - despite early gains - is likely to be eroded eventually by a growing 
overhang of foreign liabilities. Through the choices they make in the Darwinian struggle among currencies, private agents exercise a degree over public policy that is unprecedented since the dawn of the era of territorial money, going well beyond what would normally be tolerated in direct state-to-state relations. This shift in the structure of power generated by market competition...( 1998: 130)

Therefore, Cohen's repeated call for the role of politics seems weaker than before. Criticising Strange's concern about the 'ungovernance' of the world political economy, he insists on the possibility of politics. It ain't necessarily so. Yet, by implementing policies according to the game already given, by reducing it to a competition for market share, governments do not recover autonomy; they continue a system forfeiting it. Things ain't necessarily so only when they do not fundamentally alter the game (of course, even there, politics is crucially important for our lives). 'The power of governance, in short, now resides in that social institution we call the market', and the only political reaction possible now is confined to it: 'Who in the market governs?' (1998: 146, emphasis added) As he writes elsewhere: 'The rules of the game rule' (2000: 102).

This echoes his early work on theories of imperialism, but by giving a twist to his optimistic answer. He had faulted those theories for underestimating the progressive parts of capitalism. But if the rules of the game cannot be redefined within a reformist political agenda, then the post-war decades were perhaps only a Keynesian blip. Or, to put it differently and back into an IR environment, it would be a reprise of Gilpin's anxiety that the Keynesian revolution would not have domesticated capitalism but only exported its antinomies to the international stage - from where, and that is something he had not 
theorised, it may undermine the domestic solutions again (Gilpin 1987). ${ }^{16}$

So could Cohen write in the 1970 s that 'Today, both major American political parties stand in favour of some form of direct income maintenance for the poor. What could be more contrary to the traditional Marxist thesis?' (1973: 115). But this has been replaced by a bipartisan consensus and legislation that has abolished welfare as an entitlement, as in the Personal Responsibility and Work Opportunity Reconciliation Act of 1996 signed by President Bill Clinton. Similarly, Cohen (1973: 116) had criticised Baran for being far too pessimistic and determinist in his analysis, and yet the latter's analysis, which stresses the tensions between a Keynesian policy of redistribution and the spirit of capitalism, seems hardly far-fetched today (Baran 1957: 106).

This does not mean that welfare has been abolished, or that social security is not a major concern. But what has been lost is the attempt to rein in the market and not only find (more efficient) ways to adapt to it. Such attempts to rein in the market are usually summarised under the label 'de-commodification', in other words, policies aimed to take fundamental parts of human relations out of the market nexus, be they health, housing or education (leading to mixed economies). De-commodification used to be the defining characteristic of Nordic social-democratic welfare states, which are and were based on the idea of universal rights/entitlements, rather than means-tested services and insurance schemes or residual welfare compensations, as in poor laws. ${ }^{17}$ That welfare model is under huge pressure for finding the political support necessary to run it, and has reneged on many of its defining features, indeed, possibly on its very underlying logic.

Cohen's early assurance about the reformative capacities of capitalism is gone. There seems to be no way, in the present 
constellation, to redesign the rules of the game. And so the scope of the market logic increases inexorably, both by imposing constraints and by redefining the preferences of actors. Actors are trapped into even seeing how to change the game, or have themselves convinced of the sour grapes, now touting that the mere adaptation to market forces was all they ever attempted.

Governments have come to be part of a dynamic that is highly consequential and paradoxical: governments engage in a competition to keep themselves at the top of the pyramid in order to stay in control of some of its advantages, as in their currency competition. But by doing so, they 'play the game', and reinforce the very context that took control away from them in the first place. By trying to use the existing market disciplining mechanisms to their advantage, they concomitantly cement the market's definition of the constitutive rules of the game. As in Max Weber's 'iron cage' of the rationalisation of modern societies, they become prisoners of their own making.

My phrasing is not innocent, of course. Put this way, stressing his analysis of market discipline and the impersonal forces that make agents adapt so as to be caught in a game they can no longer exit, Cohen can be seen as mobilising a line of research from Weber to Foucault where rule is both impersonal and not purposeful. As Cohen writes, and readers of Foucault's Panopticon will recognise, 'Policy autonomy is threatened, but not in a purposive or hostile way. ... The veto is effective because it involves a menace, the risk of exit, that may never be implemented but is forever present. The pressure on government officials is endless' (1998: 133). And thus, unpacking Cohen's arguments over time may be fruitfully understood as moving from approaches that understand governance in terms of steering capacities to those that stress indirect rule (see Table 1). 
Benjamin Cohen on global political order: when Keynes meets realism - and beyond

\section{Table 1}

Approaches to governance and their problematiques

\begin{tabular}{|c|c|c|c|c|}
\hline & \multicolumn{4}{|c|}{ Governance } \\
\hline & \multicolumn{2}{|c|}{ As steering capacity } & \multicolumn{2}{|c|}{ As (indirect) rule } \\
\hline & HST & Regime & IPE & Foucault \\
\hline $\begin{array}{l}\text { Which concept } \\
\text { of political } \\
\text { order? }\end{array}$ & $\begin{array}{l}\text { Hegemonic } \\
\text { stability }\end{array}$ & $\begin{array}{l}\text { (Interlocking) } \\
\text { regimes }\end{array}$ & $\begin{array}{l}\text { Structure(s) of } \\
\text { domination }\end{array}$ & Governmentality \\
\hline $\begin{array}{l}\text { Which } \\
\text { problematiques } \\
\text { of governance } \\
\text { are prevalent? }\end{array}$ & $\begin{array}{l}\text { Driven by } \\
\text { agency }\end{array}$ & Driven by scope & $\begin{array}{l}\text { Driven by } \\
\text { scope, } \\
\text { mechanisms } \\
\text { and normative } \\
\text { content }\end{array}$ & $\begin{array}{l}\text { Driven by } \\
\text { mode/mechanis } \\
\text { ms }\end{array}$ \\
\hline $\begin{array}{l}\text { Which } \\
\text { problematique } \\
\text { of the diffusion } \\
\text { of power for } \\
\text { global } \\
\text { governance are } \\
\text { prevalent? }\end{array}$ & $\begin{array}{l}\text { The risk of no } \\
\text { agency of order }\end{array}$ & $\begin{array}{l}\text { Functional } \\
\text { equivalents to } \\
\text { agential order } \\
\text { within new } \\
\text { policy networks } \\
\text { and issue areas } \\
\text { and their } \\
\text { accountability }\end{array}$ & $\begin{array}{l}\text { Functional } \\
\text { equivalents to } \\
\text { agential order; } \\
\text { domination and } \\
\text { the provision of } \\
\text { basic social } \\
\text { values }\end{array}$ & $\begin{array}{l}\text { Diffusion of } \\
\text { power is global } \\
\text { governance: } \\
\text { relation between } \\
\text { liberal } \\
\text { governmentality } \\
\text { and policing }\end{array}$ \\
\hline
\end{tabular}

Source: Guzzini (2012: 28).

And with this comes the question that prompted Susan Strange to coin the expression 'un-governance' (1996: 14 and passim). This term was not meant to say that nobody is taking care of the world order (agency), or that there is no order in world affairs (structure), as Cohen reads her (see repeatedly and recently in Cohen 2014). Rather, it refers to the lack of actual political control. "[T]he key characteristic of present international regulation is "ungovernance": an increasing number of issues remain unregulated. The existing regulation ... is not the outcome of a formal political process' (see the analysis in Leander 2001: quotes from 116-17). Hence, just as Cohen writes elsewhere, effective governance through co-operation will be difficult for the sheer diffusion of agency and interests (2008: 17, original emphasis). Indeed, there is the haunting thought that this very diffusion of authority and increasing incapacity to affect the 
underlying rules of the game is all there is to order. What if this was all there can be for governance under capitalism - a governance by stealth, dis/empowering social and governmental actors, and yet (or precisely for this) with a tight grip?

\section{Conclusion: establishing analytical frameworks versus boring IPE}

This article reads Cohen's Keynesian struggle with politics in the tradition of early IPE with its emphasis on topics of power and authority in the global political economy, and in particular at the meeting point between realist and Marxist themes. In doing so, I have suggested reading him as moving from a position on governance as mere steering capacity to one that also includes indirect rule keeping a constant emphasis on the role and responsibility of politics. Even in the global political economy, politics can change. And yet, in making his conception of governance wider and more indirect and structural, the impact of politics is seen entirely within the logic of the global market economy, where state competition and capitalist strictures seem to rule out any change of the underlying rules of the game-just as it stood within the logic of international anarchy before.

This conclusion shows how this interpretation would also explain Cohen's concern with the present state of IPE. As known, he has launched a debate on the 'transatlantic divide' and on the issue of whether IPE journals are 'becoming boring' (see respectively Cohen 2007, 2010). In my final remarks, I suggest that his frustration about the state of IPE has much to do with the way fundamental questions of politics have been sidelined in a quest for a narrow scientific acceptability. By focusing on governance and domination beyond the state, his approach also includes the larger questions typical of the 'British School'. And by trying to re-conceptualise the way in which we see and analyse the world, he tries to revalorise a type of 
theorising that was dominant in the 'American School' of the 1970s and 1980s, notably Gilpin, Katzenstein, Keohane, Krasner and Nye, whom he holds up as examples. His position within the divide combines US past and British present.

Cohen does not mince his words (again similar to Strange): existing ways to approach 'finance' are not sufficiently geared towards understanding the sea-change happening just under our eyes. Indeed, our political imagination and conceptualisation is too limited to apprehend those changes in the first place. What is at stake is a different way to see the world, to see its order: 'we need a new model to improve our understanding' (1998: 8). Observers should change their analytical lenses, lest they want to keep significant aspects of the global order out of their sight. We are back to where IPE came from: a challenge to the existing conceptual setup of IR, the plea for a paradigm shift. 'World politics clearly needs to update its imagery' (1998: 16).

This call for a paradigm shift is a theoretical enterprise, since it will use evidence not to 'test' a theory but to build the conceptual frame of such a theory in the first place. It works on the constitutive functions of theory, not its instrumental function. It looks at the assumptions and concepts that make the quest for knowledge possible in the first place. Theory is here the condition of the possibility of analysis and knowledge, not only the effect of the latter. And different lenses will produce different 'looks' of the world, as so beautifully shown in Allison's Essence of Decision (1971).

While all frameworks of analysis are empirically underdetermined, inversely, the empirical world is not infinitely malleable to these conceptual lenses. Hence, neither is it that anything goes, nor is there necessarily a single lens that has the right focus. As Cohen states, 'though we may exclude obvious fantasies, there can be no appeal to 
a single, objective truth in choosing among alternative social constructs' (1998: 9).

That this type of work is theory, and hence of general - indeed literally fundamental - importance, should be self-evident; and yet it is not, at least not in Cohen's immediate environment, US political science. Here, it has become normal to think of theory only as the outcome of research and not as its precondition. Inductive rounds of generalisations are what theorising is mainly about. And, in its more radical version represented in IPE, what cannot be measured may not be analysed and therefore theorised. By implication, all the effort to persuade readers of the need for a paradigm shift will come over as, well, un-scientific, since the evidence is not used in a statistically controlled manner or positivist causal setup - when the whole point is to probe the conceptual containers in which such evidence is to be significantly understood in the first place.

Cohen's use of this type of constitutive or 'ontological' theorising (since it is about the way in which we should conceive of the world/reality - in other words, what it is/constitutes, before we empirically study it) has implications on three levels. ${ }^{18}$ On the level of the actual actors, it is about the way in which mind-sets influence understanding and action. For policy-making, this means that we had better be certain that the lenses used to view political reality are accurate, and political actors reflect on their potential multitude (I think this was Allison's main inspiration to avoid a nuclear catastrophe during the Cold War). On the level of the scientific observer, it involves a reflexivity of the way in which our scientific knowledge is based on mental images that guide our research and are themselves connected to empirical observation, yet not reducible to it, and, at times even interacting with, the social reality they purportedly only analyse ('self-fulfilling prophecies').

In effect, geography is politics. How we conceive of space has a real impact on how we 
think about rulemaking and enforcement, lending legitimacy to particular forms of dominion or authority. This insight is effectively captured by the apt term 'regime of representation' (1998: 10). ${ }^{19}$

And on the level of the practical/ethical observer, focusing on these mental images prompts the fundamental question of significance for which we do our analysis in the first place. For Cohen, this is about authority and governance. 'In choosing among alternative images, we not only privilege one reading of reality over others, we privilege one structure of power over others - one system of governance and not another' (1998: 10).

Hence, Cohen does himself a disservice when he refers to Strange or the British School as failing to theorise, and being mainly descriptive or 'normative' (2007). In fact, in 2000 he still used a basically American IPE critique of Strange when he said that her analysis was basically descriptive, since it was not built upon parsimonious hypotheses and their testing (2000: 96-98). But neither is much of his own work. Strange and Cohen make few controlled empirical generalisations, but mainly practise constitutive theory: how is order to be understood? Power? Authority? Sovereignty? What is the meaning of territory and borders? And so on. And although the choice of one framework of analysis over another (or side by side) has normative implications, they are based upon empirical analyses and checks, not on moral argument alone. They are ontological, not strictly speaking ethical. They raise 'grand' issues that much of our theorising, if concentrating on a purely explanatory level, could easily lose. 'At issue is the legitimacy of decision-making in this new, deterritorialised system of governance-a decidedly normative question' (1998: 147).

When push comes to shove, the underlying grand question is nothing less than the bargain between capitalism and liberal democracy as we know it, since the present system undermines equality before the law - money transgresses equal political rights - and undermines 
democratic accountability (1998: 147-49). Just arguing in terms of market efficiency, as libertarians may do, falls short of understanding the political dynamics at hand. When technocracies are no longer believed, when politics is allegedly not making any difference, or indeed should not make any difference, it is no surprise that 'populisms' with their clear distinction of 'us' and 'them' are on the rise. One of the main achievements of the post-war Keynesian turn was the re-appropriation of political space against anti-democratic forces. Although Cohen does not like to put political issues up-front, it seems there is a rising concern that the present global political order undermines democratic institutions directly and indirectly, as it may prompt defences of society which may further cut back on rights and encourage national and other forms of sectarianism. It is like a Polanyian nightmare where his 'double movement' (Polanyi 1957), continuously repeated, and by which the laissez-faire is answered by moves to protect society, could nowadays not end up strengthening democracies as in earlier times of 'embedded liberalism', to use Ruggie's Polanyi-inspired account (1982, 1991), but combine to undermine them.

Not much is left of a vision of global political order in which the easy realist conviction of a struggle for power was followed by a Keynesian optimism for the reformative capacities of capitalism. But when Cohen moves towards theorising the global political order from steering capacity to impersonal rule, more is at stake. By being no longer satisfied with fitting the world into existing categories, Cohen's journey also openly questions the very setup of the theories with which we deal with that world - only to see that this very inspiration of much original IPE is left by the side in the ongoing 'professionalisation' of US IPE. Beyond realism and Keynesianism, Cohen's quest for the theoretical analysis of global order leads to his quest for a new and genuinely theoretical order of our analysis, increasingly lost in the fog of US 'normal science'. 


\section{Benjamin Cohen on global political order:}

when Keynes meets realism - and beyond

\section{Notes}

1. Representative of this strand would be the English School, such as Bull (1977), or, in realist practice, Kissinger's voluminous memoirs (1979) in which the end of Bretton Woods is hardly mentioned.

2. Representative of this meeting would be the work of Robert Cox, Robert Gilpin and Susan Strange. For a general discussion, see Guzzini (1998: chapter 11).

3. Cohen sharply criticises the economists' professional disease of thinking that there are technical solutions that could easily be implemented were it not for politics or politicians and their infamous 'lack of political will' (if not worse). See, for instance, his remarks in Cohen ([1993] 2008: 68) and Cohen (1998: 91).

4. For a fully fledged account of the distinctions of interdependence, see Keohane and Nye (1977).

5. See Stephen Krasner's work on the conceptualisation of power (1985) for this take.

6. In fact, Keohane and Nye (1987) fall into the same trap when they ask for more theories of linkages between issue areas. If we had a general theory of linkages, the starting point in issue areas would not be necessary - and the realist overall structure account would be sufficient.

7. See David Baldwin's repeated discussion, as collected in (1989).

8. That such biases are mobilised through social practices is something else than saying that they are inevitably the result of individual 'choices'. In other words, structural accounts do have a vision of agency, just a different one.

9. It informs several strands of peace and conflict research.

10. They explicitly say they use, but actually do not follow, the power literature. For more faithful usages in IR/IPE at around the same time, see Gill and Law (1988) and Krause (1991).

11. Beaton (2000), cited in Barry (2003: 324). This is the rejoinder in a debate between Barry (2002) and Dowding (2003).

12. This is obviously still an important issue. For more recent analysis on this, see some earlier statements of the 'Amsterdam School in IPE', such as Van der Pijl $(1998,2004)$ and Van Apeldoorn $(2002,2004)$. For a recent discussion, see Graz and Nölke (2012). 
13. Cohen is referring to Goodman and Pauly (1993: 79).

14. As one referee indicated, this move to more structural forces also depoliticises the analysis of order. It also absolves the United States from responsibility. In doing so, it opens up a basic underlying analytical tension similar to that of Susan Strange who argues for the structural power of markets and yet the American responsibility for managing it. Few US realists have taken on US dominance and responsibility as much as Calleo (1982).

15. Despite his frequent demarcations, I think his research again parallels Susan Strange in this instance. For example, see Strange $(1989,1990)$.

16. For a discussion of this 'dialogue between Keynes and Marx', see Guzzini (1997).

17. On welfare states as agents of de-commodification, see Esping-Andersen (1990: 19-21 and passim). The issue is hence not so much distribution, but the logic in terms of which it is undertaken; it is only a means, not an end in itself. The aim was the domestication of capitalism under social and political control.

18. For a longer discussion and a comparison of different modes of theorising, see Guzzini (2013).

19. 'Regimes of representation' is a term derived from Foucaultian analysis.

\section{References}

Allison, Graham T. 1971. Essence of decision: explaining the Cuban missile crisis. Boston: Little Brown.

Baldwin, David A. 1989. Paradoxes of power. Oxford: Blackwell.

Baran, Paul A. 1957. The political economy of growth. New York, London: Monthly Review Press.

Barry, Brian. 2002. 'Capitalists rule Ok? Some puzzles about power'. Politics, Philosophy \& Economics 1(2): 155-84.

2003. 'Capitalists rule. Ok? A commentary on Keith Dowding'. Politics, Philosophy \& Economics 2 (3): 323-41. 


\section{Benjamin Cohen on global political order:}

when Keynes meets realism - and beyond

Beaton, Alistair. 2000. The little book of New Labour bollocks. London: Pocket Books.

Bull, Hedley. 1977. The anarchical society: a study of order in world politics. London: Macmillan.

Calleo, David P. 1982. The imperious economy. Cambridge, Mass.: Harvard University Press.

Cohen, Benjamin J. 1973. The question of imperialism: the political economy of dominance and dependence. London: Macmillan.

. [1976] 2008. 'The political economy of monetary reform'. In Benjamin J. Cohen, Global monetary governance. Abingdon, New York: Routledge.

1985. 'International debt and linkage strategies'. International Organization, 39 (4): 699-727.

. [1993] 2008. 'The triad and the unholy trinity: lessons from the Pacific region'. In Benjamin J. Cohen, Global monetary governance. Abingdon, New York: Routledge.

1996. 'Phoenix risen: the resurrection of global finance'. World Politics 48 (2): 268-96.

1998. The geography of money. Ithaca: Cornell University Press.

2000. 'Money and power in world politics'. In Thomas Lawton, James N Rosenau and Amy C Verdun (eds), Strange power: shaping the parameters of international relations and international political economy. Aldershot: Ashgate.

2007. 'The transatlantic divide: Why are American and British IPE so different?'. Review of International Political Economy 14 (2): 197-219.

2008. Global monetary governance. Abingdon, New York: Routledge.

2010. 'Are IPE journals becoming boring?'. International Studies Quarterly 54 (4): 887-91.

2014. 'Money, power, authority'. Paper presented at the FLACSO-ISA convention, Buenos Aires, 23-25 July.

Dowding, Keith. 2003. 'Resources, power and systematic luck: a response to Barry'. Politics, Philosophy \& Economics , 2 (3): 305-22. 
Esping-Andersen, Gøsta. 1990. The three worlds of welfare capitalism. Cambridge: Polity Press.

Gill, Stephen and David Law. 1988. The global political economy. Brighton: Harvester Wheatsheaf.

Gilpin, Robert, with the assistance of Jean Gilpin. 1987. The political economy of international relations. Princeton: Princeton University Press.

Goodman, John B and Louis Pauly. 1993. 'The obsolescence of capital controls? Economic management in an age of global markets'. World Politics 46 (1): 50-82.

Graz, Jean-Christophe and Andreas Nölke. 2012. 'The limits of transnational private governance'. In Stefano Guzzini and Iver B Neumann (eds), The diffusion of power in global governance: International Political Economy meets Foucault. Houndmills: Palgrave Macmillan.

Guzzini, Stefano. 1993. 'Structural power: the limits of neorealist power analysis'. International Organization 47 (3): 443-78.

1997. 'Robert Gilpin: the realist quest for the dynamics of power'. In Iver B Neumann and Ole Wæver (eds), The future of international theory: masters in the making? London, New York: Routledge.

1998. Realism in international relations and international political economy: the continuing story of a death foretold. The New International Relations. London, New York: Routledge.

2000. 'Strange's oscillating realism: opposing the ideal - and the apparent'. In Thomas C Lawton, James N Rosenau and Amy C Verdun (eds), Strange power: shaping the parameters of international relations and international political economy. Aldershot: Ashgate.

. 2012. 'The ambivalent "diffusion of power" in global governance'. In Stefano Guzzini and Iver B Neumann (eds), The diffusion of power in global governance: international political economy meets Foucault. Houndmills: Palgrave Macmillan.

2013. 'The ends of international relations theory: stages of reflexivity and modes of theorizing'. European Journal of International Relations, 19 (3): $521-41$.

Helleiner, Eric. 1996. States and the re-emergence of global finance: from Bretton Woods to the 1990s. Ithaca, NY: Cornell University Press. 


\section{Benjamin Cohen on global political order:}

when Keynes meets realism - and beyond

Hirschman, Albert O. [1945] 1980. National power and the structure offoreign trade. Expanded edition. Berkeley: University of California Press.

James, Scott C and David A Lake. 1989. 'The second face of hegemony: Britain's repeal of the Corn Laws and the American Walker Tariff of 1846'. International Organization 43 (1): 1-29.

Keohane, Robert O and Joseph S Nye Jr. 1977. Power and interdependence: world politics in transition. Boston: Little Brown.

1987. 'Power and Interdependence Revisited'. International Organization 41 (4): 725-53.

Kissinger, Henry A. 1979. The White House years. Boston: Little Brown.

Krasner, Stephen D. 1985. Structural conflict: the Third World against global liberalism. Berkeley: University of California Press.

Krause, Keith. 1991. 'Military statecraft: power and influence in Soviet and American arms transfer relationships'. International Studies Quarterly 35 (3): 313-36.

Leander, Anna. 2001. 'Dependency today: finance, firms, Mafias and the state: a review of Susan Strange's work from a developing country perspective'. Third World Quarterly 22 (1): 115-28.

Lukes, Steven. 1974. Power: a radical view. London: Macmillan.

Morriss, Peter. 1987. Power: a philosophical analysis. Manchester: Manchester University Press.

Onuf, Nicholas and Frank F Klink. 1989. 'Anarchy, authority, rule'. International Studies Quarterly 33 (2): 149-73.

Polanyi, Karl. 1957. The great transformation: the political and economical origins of our time. Beacon Hill: Beacon Press.

Ruggie, John Gerard. 1982. 'International regimes, transactions, and change: embedded liberalism in the postwar economic order'. International Organization 36 (2): 379-415.

1991. 'Embedded liberalism revisited: institutions and progress in international economic relations'. In Emanuel Adler and Beverly Crawford (eds), Progress in postwar international relations. New York: Cambridge University Press.

1998. 'What makes the world hang together?: neo-utilitarianism and the social constructivist challenge'. International Organization 42 (4): 855-86. 
Sen, Gautam. 1984. The military origins of industrialisation and international trade rivalry. London: Frances Pinter.

Strange, Susan. 1986. Casino capitalism. London: Basil Blackwell.

1989. 'Toward a theory of transnational empire'. In Ernst-Otto Czempiel and James Rosenau (eds), Global changes and theoretical challenges: approaches to world politics for the 1990s. Lexington, MA: D C Heath \& Co.

1990. 'The name of the game'. In N Rizopoulos (ed), Sea-changes: American foreign policy in a world transformed. New York: Council on Foreign Relations Press.

1994. 'Wake up, Krasner! The world has changed'. Review of International Political Economy 1 (2): 209-19.

1996. The retreat of the state: the diffusion of power in the world economy. Cambridge: Cambridge University Press.

Van Apeldoorn, Bastiaan. 2002. Transnational capitalism and the struggle over European integration. London, New York: Routledge.

(ed). 2004. Special issue on 'Transnational historical materialism: the Amsterdam International Political Economy project'. Journal of International Relations and Development, vol. 7, no. 2.

Van der Pijl, Kees (1998) Transnational Classes and International Relations. London, New York: Routledge.

2004. 'Two faces of the transnational managerial cadre under neo-liberalism'. Journal of International Relations and Development 7 (2): 177-207.

Waltz, Kenneth N. 1979. Theory of international politics. Reading: Addison-Wesley.

\section{Abstract}

\section{Benjamin Cohen on global political order: when Keynes meets realism - and beyond}

This article analyses the trajectory of Benjamin J. Cohen's work by focusing on his ongoing concern with the nature and governance of world order. It 


\section{Benjamin Cohen on global political order:}

when Keynes meets realism - and beyond

does so by playing out his debt to realism and to Keynesianism. In a first moment, Cohen criticises the economic determinism of dependency scholarship, while turning to political realism, and then to possible Keynesian co-operation under anarchy: agents have the power to affect positive change. Later, Cohen the disillusioned Keynesian, watching how the possible reform of financial markets is marginalised by politicians and academics alike, shifts his analysis to more structural aspects of governance or rule that affect actors' preferences. I draw two conclusions. First, in this shift towards theorising the global political order away from steering capacity towards impersonal rule and bias, Cohen also questions the very setup of the theories with which we deal with that world - only to see that this very inspiration of original IPE is abandoned in the course of the ongoing 'professionalisation' of IPE as practised in the United States. Second, his analysis seems to incorporate a warning. The underlying grand question is nothing less than the bargain between capitalism and liberal democracy as we know it, since the present system undermines equality before the law - money trumps equal political rights - and undermines democratic accountability. One of the main achievements of the post-war Keynesian turn was the reappropriation of political space from anti-democratic forces. Therefore, the decline of Keynesianism could provoke a Polanyian nightmare in which the 'double movement' by which the laissez-faire is answered by moves to protect society does not strengthen democracies, as in earlier times of 'embedded liberalism', but undermines them instead.

Keywords: Dependency - Structural Power - International Finance - Karl Polanyi - Embedded Liberalism - Global Governance 